\title{
ФОРМИРОВАНИЕ ЛИНГВОКУЛЬТУРОЛОГИЧЕСКОЙ КОМПЕТЕНЦИИ УЧАЩИХСЯ ПРИ ИЗУЧЕНИИ ФРАЗЕОЛОГИИ НА УРОКАХ РУССКОГО ЯЗЫКА
}

\author{
Артюшков Игорь Викторович \\ доктор филологических наук, профессор \\ Насырова Альбина Рустамовна \\ ФГБОУ ВО «Башкирский государственный \\ педагогический университет им. М. Акмуллы»
}

\begin{abstract}
Аннотация: В статье обосновывается значимость лингвокультурологической компетенции в обучении русскому языку в школе. Рассматривается, как изучение фразеологии с учетом межпредметных связей влияет на формирование лингвокультурологической компетенции и способствует формированию языковой личности учащихся. Даются примеры работы с фразеологизмами и необходимые комментарии.
\end{abstract}

Ключевые слова: Лингвокультурологическая компетенция, фразеологизм, текст, задания, межпредметная связь.

\section{FORMATION OF LINGUISTIC AND CULTURAL COMPETENCE OF STUDENTS IN THE STUDY OF THE PHRASEOLOGY AT RUSSIAN LANGUAGE}

\section{Artyushkov Igor Nasyrova Albina}

\begin{abstract}
The article contains a justification of the importance of linguistic and cultural competence in teaching Russian at school. The article considers how the study of phraseological units affects the formation of linguistic and cultural competence and contributes to the formation of the student's language personality. Examples of working with phraseological units are given and intersubject communication is considered.
\end{abstract}




\section{СОВРЕМЕННОЕ ОБРАЗОВАНИЕ:

Key words: linguistic and cultural competence, idioms, and text analysis, tasks, inter-subject relationship.

Современное школьное образование, согласно новому Федеральному государственному стандарту образования, включает в себя не только обучение, но и развитие личности, способной принимать ответственные решения, успешно выполнять любые задачи и отвечать за результат, и опирается на компетентностный подход [1, с. 6]. Особая роль в этом принадлежит филологическому образованию. Задачей изучения русского языка в школе является обогащение словарного запаса учащихся, развитие у них всех типов речевой деятельности, умения владеть русским литературным языком как средством общения в соответствии с коммуникативной целью и ситуацией общения, нормами устной и письменной речи, правилами речевого этикета.

Конкретизированные цели образования в области русского языка решаются через формирование и совершенствование компетенций: коммуникативной, языковой, лингвистической, лингвокультурологической. Компетентностный подход в изучении русского языка обеспечивает единство языкового, речемыслительного, интеллектуального, духовно-нравственного и эстетического развития учащихся. С сожалением, приходится констатировать, что в настоящее время уровень лингвокультурологической компетенции учащихся, по сравнению с другими компетенциями, является весьма низким. Это делает задачу формирования и совершенствования данной компетенции особенно важной и актуальной.

А.Я. Флиер отмечает: «Культурологическая компетенция - качество личности, позволяющее ощущать себя объектом культурно-исторического процесса, иметь познания в разнообразных областях науки и искусства, понимать закономерности развития культуры как процесса по созданию, сохранению и трансляции общечеловеческих ценностей, и умение общаться в современном мире, оперируя реалиями, обычаями, образами не только своего народа» [2, с. 91].

Согласно Л.Г. Саяховой, «лингвокультурологическая компетенция - это система знаний о жизненном опыте русского народа, его культуре, национальных традициях, а также личностные качества, нравственно-этические ценности, приобретаемые в процессе освоения системы культурных ценностей, 
выраженных в языке и регулирующих коммуникативное поведение носителей этого языка» [3, с. 94].

Методологические идеи И.И. Ушинского, Ф.И. Буслаева, И.И. Срезневского являются фундаментом процесса обучения русскому языку и усвоения культуры народа. Развитие лингвокультурологических знаний связано с историческими событиями, культурно-историческими и социальными ассоциациями языка. Фразеологизмы являются связующим звеном в цепи поколений. Фразеология - своего рода «энциклопедия русской жизни», богатое наследие, которое оставили нам наши предки, их опыт. Фразеологические единицы представляют собой не только факты языка, но и факты культуры, они отражают особенности национального мировосприятия. Образность, обобщенно-метафорический смысл, оценочность и экспрессивность - все это является причиной того, что фразеологизмы живут по сей день. Как отмечает В.Н. Телия, фразеологический состав языка - «это зеркало, в котором лингвокультурная общность идентифицирует свое национальное самосознание» $[4$, с. 9$]$.

В последние годы в России наблюдается падение общей культуры речи, снижение уровня владения родным языком ослабление интереса к литературному чтению, преобладание «телеграфного стиля» общения в интернете и мобильных приложениях, увеличение интереса к компьютерным играм. Но, осваивая богатство русской классической литературы и литературы XX века, учащиеся постоянно встречаются с различными устойчивыми оборотами, которые надо правильно понимать, «расшифровывать». Фразеологические обороты нередки в речи людей, с которыми постоянно сталкиваются школьники в обыденной жизни или в ситуации делового (учебного) общения.

Ошибки учащихся в употреблении фразеологических единиц часто связаны с неумением отличить фразеологический оборот от свободного словосочетания, незнанием его точного значения, немотивированным изменением состава фразеологизма («глупа как Валаамова ослица» вместо «упряма как Валаамова ослица» или «нельзя опускать руки вниз» вместо «нельзя опускать руки»), допускают смешение нескольких фразеологических оборотов в одном («чаша терпения лопнула» вместо «чаша терпения переполнена» и «терпение лопнуло»). 


\section{СОВРЕМЕННОЕ ОБРАЗОВАНИЕ:

Лингвокультурологическая компетенция, к которой необходимо привести ученика, - это умение осознавать этнокультурную окрашенность языка, способность использовать национально маркированную лексику.

Знакомство с фразеологизмами у учащихся происходит в 6 классе. При формировании понятия о фразеологизмах очень важно научить учеников отличать их от свободных словосочетаний. Также нужно объяснить, что фразеологизмы - это устойчивые словосочетания, они не создаются каждый раз заново, состав фразеологизмов не изменяется. На другие языки фразеологизмы не переводятся, но в разных языках есть близкие по смыслу устойчивые выражения.

В школьном курсе русского языка на изучение раздела фразеологии отводится небольшое количество часов, поэтому необходимо искать любую возможность использовать этот фразеологический материал для формирования лингвокультурологической компетенции учащихся. Освоение фразеологизмов - постепенный и длительный процесс. Обогащение речи детей фразеологизмами, усвоение их значения и особенностей употребления требует целенаправленной, специально организованной работы. Школьники любых возрастных групп с большим интересом и увлечением включаются в работу с фразеологизмами.

Во фразеологизмах сохраняются многие оставшиеся в прошлом языковые явления, относящиеся к лексике, морфологии, старославянской орфографии. Многочисленны примеры фразеологизмов, содержащих лексику, вышедшую из активного употребления: бить баклуши, играть в бирюльки, встать на дыбы, лезть на рожсо, аршин проглотить, семь пядей во лбу, косая сажень в плечах, грош цена, как зеницу ока, один как перст, сбить с панталыку, души не чаять, кануть в лету, по сей день, кой ляд и др.

Способность свободно и быстро находить фразеологизмы позволяет быстро определять границы членов предложения, что ведет к правильной постановке знаков препинания и соблюдения грамматических норм. Знания по русской фразеологии можно использовать и в старших классах на уроках литературы. Это могут быть задания-исследования поискового характера, а также конкурсы, викторины, олимпиады, проекты. Изучение фразеологизмов и использование их в речи помогает увеличить словарный багаж, сделать речь более разнообразной и выразительной, а также повысить уровень общей культуры учащихся. 
Обращение к фразеологическим словарям в процессе работы способствует активизации поисковой, исследовательской деятельности учащихся, учит их работать со справочной литературой и грамотно осуществлять поиск, правильно понимать словарную статью и правильно анализировать фразеологизмы.

Учитель в процессе обучения может использовать как игровые моменты, так и целые уроки-игры (уроки-путешествия, уроки-викторины, урокисоревнования, уроки-квесты, уроки-спектакли, уроки-творческие мастерские), что не только существенно повышает познавательный интерес учащихся к предмету, но и расширяет их знания по истории и культуре страны, создает необходимую базу для лингвистического анализа художественного текста в дальнейшем.

Существует много форм и видов работы с фразеологизмами:

1. Нахождение фразеологизмов в тексте и/или в словаре и выяснение их лексического значения (толкование).

2. Составление предложений с фразеологизмами.

3. Замена слов или свободных словосочетаний в тексте фразеологическими оборотами.

4. Поиск сведений об истории происхождения фразеологизмов.

5. Составление предложений, где выражение будет употребляться и в качестве свободного словосочетания, и в качестве фразеологизма.

6. Определение фразеологизмов по рисунку.

7. Создание иллюстраций к фразеологизмам.

8. Группировка фразеологизмов по происхождению (исконно русские, старославянские, библейские, профессиональные, из мифологии, из художественной литературы).

9. Группировка фразеологизмов по стилистической окрашенности (разговорные, нейтральные, книжные).

10. Нахождение «лишнего» фразеологизма в группе предложенных.

11. Восстановление фразеологизмов (нахождение отсутствующего слова) без предложенных вариантов.

12. Восстановление фразеологизмов выбором одного из предложенных слов к каждому фразеологизму.

13. Нахождение и исправление ошибок в употреблении фразеологических оборотов. 


\section{СОВРЕМЕННОЕ ОБРАЗОВАНИЕ:

14. Написание сочинения, темой которого выступает фразеологический оборот.

15. Составление теста для оценивания уровня теоретических знаний по фразеологии.

16. Выполнение теста на определение уровня теоретических знаний по фразеологии.

17. Составление кроссворда на знание фразеологических оборотов.

18. Инсценировка фразеологизмов.

19. Съемка видеороликов «История одного фразеологизма».

Формирование лингвокультурологической компетенции предполагает:

- многоаспектное изучение фразеологических единиц;

- отработку умения анализировать фразеологические единицы;

- обогащение фразеологического словаря учащихся;

- предупреждение ошибок в употреблении фразеологизмов в дальнейшем;

- использование на уроке текстов с национально-культурным компонентом, сведений о русской культуре, быте, традициях, обычаях, духовных и материальных ценностях русского народа.

При изучении фразеологии весьма эффективным является использование межпредметных связей. Эти связи необходимо устанавливать для создания единой системы понятий. По утверждению Я.А. Коменского, «невозможно систематизировать знания учеников без установления связей между дисциплинами. Всё, что находится во взаимной связи, должно преподаваться в такой же связи» [5, с. 29]. Особо подчеркивал значимость межпредметных связей К.Д. Ушинский: «Знания и идеи, сообщаемые, какими бы то ни было науками, должны органически строиться в светлый и, по возможности, обширный взгляд на мир и его жизнь» [6, с. 178].

Для осуществления межпредметных понятийно-терминологических связей можно предложить учащимся найти примеры фразеологизмов из курсов физики, химии, биологии и географии. Такими примерами могут быть следующие выражения:

1) из физики: абсолютный нуль (минимальный предел температуры или пустой, неинтересный человек), теорема Ферма (одна из самых популярных теорем математики, считавшаяся недоказуемой с 1637 по 1995 г., или символ неразрешимой научной задачи, чего-то нерешаемого), цеепная реащия (ряд 
превращений, поступков, состояний, вызывающих друг друга), метать громы и молнии (ругаться, сердиться, бушевать), сделать упор, брать силой, довести до белого каления;

2) из биологии: собака Павлова (подопытное существо), желторотый птенец, одного поля ягода;

3) из химии: сгореть от стыда, стереть в порошок.

Связь фразеологии с историей осуществляется через изучение изречений античных и средневековых философов, военачальников и других известных личностей, которые оставили свой след в истории. Примером может быть выражение Сократа Платон мне друг, но истина дороже. Также много фразеологизмов пришло из мифов и легенд: дамоклов меч, драконовы законы, сизифов труд, ахиллесова пята и др. Возникновение многих фразеологизмов связано с обычаями и укладом жизни наших предков: зарубить на носу, бить баклуши, держать камень за пазухой, на лице написано и т.д. Учитель на уроке истории при изучении какой-либо конкретной темы, может рассказать о соответствующем фразеологизме и его происхождении.

Ученикам начальных классов можно предложить изобразить фразеологизмы, как они их понимают (особенно интересно предлагать те выражения, значения которых школьники еще не знают), таким образом может реализоваться связь русского языка и уроков изобразительного искусства.

В шестом классе на уроках при изучении фразеологии ученикам интересна будет связь русского языка с физикой, историей и литературой. Для этого можно провести интегрированный урок по теме «Путешествие в Древнюю Грецию», так как по истории дети изучают историю Древнего мира, по литературе - мифологию, а также получают начальные знания по физике. Читая мифы про Зевса, учащиеся встретят фразеологизм метать гром $u$ молнию, а в мифах про Ахиллеса - фразеологизм ахиллесова пята.

Фразеология тесно связана с литературой. Часто упражнения в учебниках содержат примеры из художественных произведений, которые изучаются параллельно на уроках литературы. Например, в следующих предложениях необходимо найти фразеологизмы и объяснить их значение.

1. Твой отец добрый малый, - промолвил Базаров, - но он человек отставной, его песенка спета. (И. Тургенев)

Фразеологизмы: добрый малый со значением «хороший человек», песенка спета - «конец чего-нибудь». 
2. Вешать можно на гвоздь

Полотение и трость,

Лампу, плащ или шапку.

И верёвку, и тряпку...

Но никогда и нигде

Не вешайте носа в беде! (Ю. Коринеи)

Фразеологизм не вешать нос имеет значение «не унывать».

3. И какой толк, если тебе хоть пятерку с плюсом выставят, когда у тебя понимания на круглый ноль. Кому будет охота растить олуха царя небесного (Л. Кассиль).

Фразеологизмы: круглый ноль - «никакой, отсутствие чего-либо»; олух царя небесного - «разиня, простак».

4. Ночной разбойник, дуэлист... и крепко на руку нечист. (А. Грибоедов)

Фразеологизм на руку нечист - «склонен к мошенничеству, воровству».

В качестве дидактического материала на уроках русского языка можно использовать отрывки из художественных произведений. При этом работа с текстом должна быть комплексной и включать в себя задания не только по фразеологии, но и по орфографии, морфологии, синтаксису, стилистике. На уроках литературы следует обращать внимание на использование фразеологизмов, с помощью которых создаются яркие речевые характеристики персонажей. В шестом классе изучаются произведения А.П. Чехова. Ученики в рассказе «Злоумышленник» встретятся с фразеологизмами с неба упал, точно вчера родился, здорово живешь,дураку закон не писан, иарица небесная, а в рассказе «Хирургия» - по гроб жизни, дух перевести.

Работа над значениями и употреблением фразеологизмов, составление с ними предложений, способствует включению их в речь учащихся и грамотному и уместному использованию.

Фразеология способствует интеллектуальному развитию, расширяет общий кругозор, развивает воображение и мышление, способствует реализации творческих способностей, увеличивает возможности памяти учащихся и в конечном счете способствует развитию у школьников лингвокультурологической компетенции. 


\section{Список литературы}

1. Федеральный государственный образовательный стандарт основного общего образования, утвержденный приказом № 1897 Министерства образования и науки Российской Федерации от 17.12.201.

2. Флиер А.Я. Культурология для культурологов: Учебное пособие для магистрантов, аспирантов и соискателей, а также преподавателей культурологии. 2-е изд., испр. и доп. - М.: МГУКИ, 2009. - 699 с.

3. Саяхова Л.Г. Методология и методическая система формирования лингвокультурологической компетенции тюркоязычных учащихся на уроках русского языка. - Уфа: РИЦ БашГУ, 2010. - 292 с.

4. Телия В.Н. Русская фразеология. Семантический, прагматический и лингвокультурологический аспекты. - М.: Школа «Языки русской культуры», 1996. $-288 \mathrm{c}$.

5. Коменский Я.А., Локк Д., Руссо Ж.-Ж., Песталоцци И.Г. Педагогическое наследие / Сост. В.М. Кларин, А.Н. Джуринский. - М.: Педагогика, 1987. - 416 с.

6. Ушинский К.Д. Собрание сочинений. Т.3. - М., «Знание», 1948. 416 с. 